Available online at : http://journal.unj.ac.id/unj/index.php/gjik

Gladi : Jurnal Ilmu Keolahragaan 12 (03) Special Issue 2021, 45-51

Permalink/DOI: https://doi.org/10.21009/GJIK.123.07

\title{
ANALYSIS OF FOOTBALL DRIBBLING SKILLS
}

\author{
Ades Fathu Fiyadinallah ${ }^{1}$, Yusmawati ${ }^{1}$, Wahyuningtyas Puspitorini ${ }^{1}$ \\ ${ }^{1}$ Physical Education, Postgraduate University of Jakarta, Jakarta State University Complex Bung Hatta \\ Building J1. Rawamangun Muka, East Jakarta, INDONESIA 13220
}

Correspondiing author. Email : AdesFathuFiyadinallah_9903820014@mhs.unj.ac.id ${ }^{1}$

\begin{abstract}
Abstrak This research is motivated by the existence of various forms of soccer dribbling skill errors, namely first touch, coordination, and ball feeling as well as characteristic causes based on observations made by researchers, the facts in the field state that when the teacher delivers soccer dribbling material there are still many students who lack focus about understanding the strategy that the coach gives to students will have an impact on formations that cannot be applied during play. The next factor is that not many teachers/coaches apply various training models to the learning process, so it tends to be monotonous. The reason the author observes this problem is to find out, analyze and correct the form of football dribbling skills errors. The data collection method used in this research is a survey method with the locomotor skills test technique and the skill development phase test. The research sampling technique used a total sampling technique with a total of 40 responses from some class III and IV extracurricular students of Al-Fath BSD Elementary School, South Tangerang City. The research variables were basic first touch skills, coordination, and ball feeling in doing soccer dribbling. Analysis of research data using descriptive percentages. Based on the results of the assessment analysis, it can be concluded that the form of errors in the dribbling skills of the III and IV graders of football extracurricular is first touching $18 \%$, coordination $45 \%$, and ball feeling $15 \%$. The cause of errors that occur in dribbling skills is a lack of coordination ability, this can be seen in the skill test percentage indicator after being analyzed.
\end{abstract}

Keywords: Forms of Football Dribbling Mistakes, Elementary School Extracurricular Students 


\section{INTRODUCTION}

The game of football is a form of sport that uses soccer balls (Taufik, 2019). In the game of football, there are several basic technical movements including the first touch, passing control, shooting, dribble, and heading (Danurwindo et al., 2017). Football is a sport that is in great demand both among adults and children, in schools football is also a sport that is very popular with many students, especially male students (Taufiqurriza, 2012). In this study, the researchers took one of the basic movements of football, namely dribbling, according to (Afonshin et al., 2020; Giordano et al., 2019) dribbling is one of the most important parts of soccer because dribbling is one of the effective ways to get past your opponent. Then the formation, tactics, and strategy of football is now a major problem that is often and common to the wider community who wants to learn it selftaught because the coaches provide strategies and formations to improve the quality of the players and become an attraction for the general public who is observing and observing a football club.

Based on observations made by researchers, according to (Danurwindo et al., 2017) Broadly speaking, the training process is divided into several stages, namely Planning, Preparation, Implementation, and Evaluation, this process is a cycle that continues to rotate in training. We need to note that this quote has been staged in training, This process attracts researchers to analyze and develop the training process so that the success of a team becomes a benchmark in a training process. The gaps experienced by trainers depend on the training process itself, how a trainer does the process properly. According to (Suherman,
2018; Suherman \& Sari, 2019) in general, this research aims to obtain a foundation in considering a work procedure, improve and improve learning conditions, and the quality of learning. Specifically, this study aims to determine the increase in extracurricular student learning outcomes towards soccer dribbling skills with several test indicators.

Based on these problems, the author wants to examine the results of soccer dribbling exercises which can improve the first touch, coordination, and ball feeling skills performed by students, so that students consciously understand the concept of dribbling exercises given by the coach in real soccer games. Therefore, the authors conducted a study entitled "Analysis of Football Dribbling Skills".

\section{METHODS}

The data collection method used in this research is a survey method with locomotor skills test techniques and a test of the development phase of skills in doing football dribbling for elementary school extracurricular students, according to (Jayusman \& Shavab, 2020; Putra, 2015; Sidabutar, 2020) Descriptive research is not intended. to test a particular hypothesis, but only describes what it is about a variable. So it can be concluded that quantitative descriptive research in this research is to see, review and describe in numbers about the object under study as it is and draw conclusions about it according to the phenomena that appear at the time the research was carried out.

The research sampling technique used total sampling technique with a total of 40 responses from some class III and IV extracurricular students of Al-Fath BSD Elementary School, South Tangerang City, consisting of 20 class 
III students and $201 \mathrm{~V}$ class student's responses, the data collected were analyzed using descriptive percentage (Ariningsih et al., 2012), according to (Sultoni, Imam Gunawan, 2018) population is a group of similar organisms that have the same characteristics. Then according to (Asbari Masduki, Priyono Budi Santoso, 2019), The sample is a part or representative of the population studied.

The sports skill test aims to measure the skills of students in a sport (Valentini et al., 2018). This test will reveal the mastery of basic technical skills in a sport. This study used a test instrument for basic skills (1) first touch, (2) coordination, and (3) ball feeling. The skill test is arranged based on the indicators needed in this study.

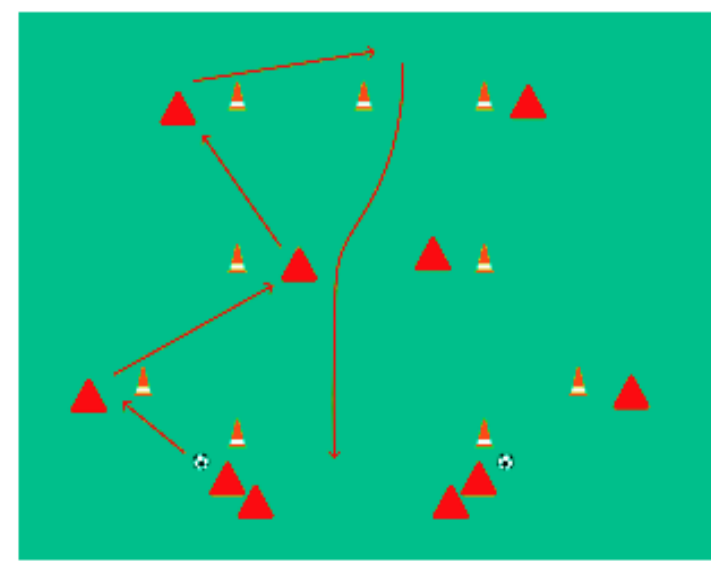

Figure 1. First Touch Skills Test

(Danurwindo et al., 2017)

First touch skills test, organization: - Create an organization as shown. Set the distance according to the level. Implementation: - The player passes to the player at the following post to facilitate the first touch forward. - The player in the following post releases himself from the cone, takes the body position, can see his friend with the ball, can see the next target. •
The first touch upon receiving the ball must go to the next target. And so on. Player in post 4 dribbles back to the first post.

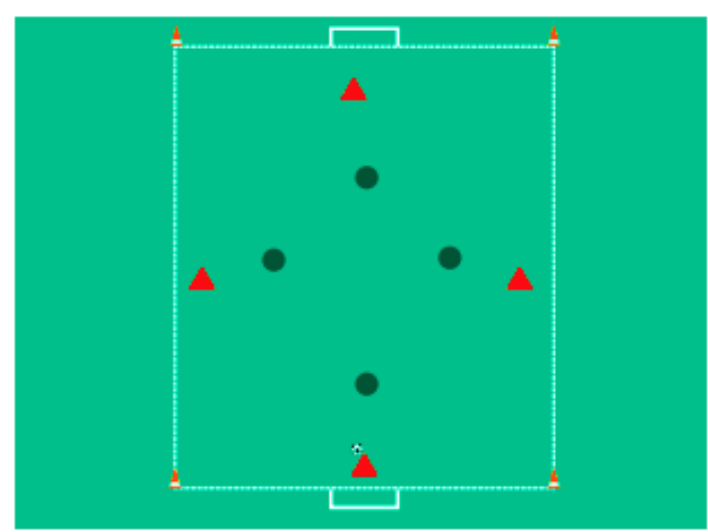

Figure 2. Coordination Skills Test (Danurwindo et al., 2017)

Coordination skills test, organization: - Create a grid of $40 \times 20 \mathrm{~m}$ size (adjust level). - Install 2 gates of $2 \times 5 \mathrm{~m}$ size (adjust level). - Divide players into 2 teams consisting of 4 people from each team. Implementation: - Play 4 vs 4 without a goalkeeper, everyone in play. Calculate scores to motivate players. Switch compositions and positions so that the players continue to feel a new atmosphere. - When the players are getting used to it, start teaching simple principles: - diamond formation. $\cdot$ large rhombus when in control of the ball. $\cdot$ a small diamond when the opponent has control of the ball.

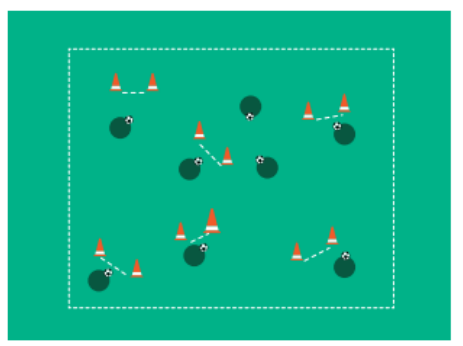

Figure 3. Ball Felling Skill Test (Danurwindo et al., 2017) 
Test of ball feeling skills, organization: - Create a grid of $30 \times 20 \mathrm{~m}$ size (adjust level). $\bullet 1$ person 1 ball, put 6 goals $(2 \mathrm{~m}$ wide) randomly. Execution: - Players dribble freely in the area. Every chance there is, players must dribbling into the door of the kingdom. At the door of the kingdom, players can be asked to - stop stepping on the ball, then dribble again. - Variation of ball feeling: push-pull with the sole, slide left-right with the sole, slap left-right with the inside of the foot. - turning variations: inner leg, outer leg. $\bullet$ Make it a competition by having players enter as many doors as possible in 10 seconds. • The player who enters the most doors wins.

\section{RESULTS}

Data analysis was carried out by using a percentage of what could be called a percentage correction (Anggraeni \& Saryono, 2013; Hidayat, 2017; Hopper, Crhistopher A.; Davis, 1988). The results of the research on tests of basic skills first touch, coordination, and ball feeling in doing soccer dribbling on male extracurricular student's class III and IV of Al-Fath BSD Elementary School, South Tangerang City were obtained through methods. Based on the results of the first touch test assessment, it can be seen that there are 7 students (18\%) who are in the poor category, 7 students $(18 \%)$ are in enough category, 17 students $(43 \%)$ are in a good category and 9 students $(23 \%)$ are included. in the very good category. Based on the results of the research on the coordination test, it can be seen that there are 18 students (45\%) who are in the poor category, 6 students $(15 \%)$ are in the sufficient category, 8 students $(20 \%)$ are in a good category and 8 students $(20 \%)$ are included in the category. very good category. Based on the results of the ball feeling test, it can be seen that 6 students $(15 \%)$ are in the poor category, 11 students $(28 \%)$ are in the sufficient category, 15 students $(38 \%)$ are in a good category and 8 students $(20 \%)$ are included in the category. in the very good category.

Based on the results above, it can be seen that in general, the basic skills level of soccer dribbling in extracurricular classes III and IV are in the moderate category. It can be concluded that the dribbling coordination skills are in the poor category, namely 18 students $(45 \%)$ of the number of responses who have different categories

Table 1. Results of the Assessment of the Basic Skills for the Game of Football

\begin{tabular}{|c|c|c|c|c|}
\hline \multicolumn{5}{|c|}{ GRADE III and IV } \\
\hline \multicolumn{2}{|c|}{ FIRST TOUCH } & \multirow[b]{2}{*}{ Category } & \multirow[b]{2}{*}{$\begin{array}{c}\text { Frequenc } \\
\mathbf{y}\end{array}$} & \multirow[b]{2}{*}{$\begin{array}{c}\text { Percentage } \\
(\%)\end{array}$} \\
\hline No & $\begin{array}{l}\text { Skill } \\
\text { Score }\end{array}$ & & & \\
\hline 1 & $86-90$ & Very good & 9 & $23 \%$ \\
\hline 2 & $81-85$ & Good & 17 & $43 \%$ \\
\hline 3 & $76-80$ & Enough & 7 & $18 \%$ \\
\hline 4 & $71-75$ & Less & 7 & $18 \%$ \\
\hline \multicolumn{2}{|c|}{ Total } & & 40 & $100 \%$ \\
\hline \multicolumn{2}{|c|}{$\begin{array}{l}\text { COORDINATION } \\
\end{array}$} & & & \\
\hline No & $\begin{array}{c}\text { Skill } \\
\text { Score } \\
\end{array}$ & Category & $\begin{array}{c}\text { Frequen } \\
\text { cy }\end{array}$ & $\begin{array}{c}\text { Percentage } \\
(\%)\end{array}$ \\
\hline 1 & $86-90$ & Very good & 8 & $20 \%$ \\
\hline 2 & $81-85$ & Good & 8 & $20 \%$ \\
\hline 3 & $76-80$ & Enough & 6 & $15 \%$ \\
\hline 4 & $71-75$ & Less & 18 & $45 \%$ \\
\hline \multicolumn{3}{|c|}{ Total } & 40 & $100 \%$ \\
\hline \multicolumn{2}{|c|}{ BALL FEELING } & & & \\
\hline No & $\begin{array}{c}\text { Skill } \\
\text { Score }\end{array}$ & Category & $\begin{array}{l}\text { Frequen } \\
\text { cy }\end{array}$ & $\begin{array}{c}\text { Percentag } \\
\text { e }(\%)\end{array}$ \\
\hline 1 & $86-90$ & $\begin{array}{l}\text { Very } \\
\text { good }\end{array}$ & 8 & $20 \%$ \\
\hline 2 & $81-85$ & Good & 15 & $38 \%$ \\
\hline 3 & $76-80$ & Enough & 11 & $28 \%$ \\
\hline 4 & $71-75$ & Less & 6 & $15 \%$ \\
\hline \multicolumn{3}{|c|}{ Total } & 40 & $100 \%$ \\
\hline
\end{tabular}

How to calculate it using Microsoft Excel by making an 
Gladi Jurnal Ilmu Keolahragaan, 12 (03), July- 49

Ades Fathu Fiyadinallah, Yusmawati, Wahyuningtyas Puspitorini

assessment rubric table first as in Table

2 then averaged.

Tabel 2. Dribbling Technique Skills Assessment Rubric Using Inner, Outer Legs and Instep (Evan et al., 2002; Viggita \& Arikunto, 2020)

\begin{tabular}{|c|c|}
\hline \multicolumn{2}{|l|}{ First Touch } \\
\hline Score & The initial attifude of doing the movement \\
\hline Good (3) & $\begin{array}{l}\text { 1) Start with a standing posture. } \\
\text { 2) The gaze is always looking at the ball. } \\
\text { 3) The ball is in front of the body. }\end{array}$ \\
\hline Moderate (2) & Only two criteria are performed correctly. \\
\hline Less (1) & Only one criterion was performed correctly. \\
\hline Score & The attitude of carrying out the movement \\
\hline Good (3) & $\begin{array}{l}\text { 1) The strongest feet prepare to receive the ball. } \\
\text { 2) Push the ball forward using your inner, outer or instep. } \\
\text { 3) The feet that do not push the ball ensure that they are opened and balanced. }\end{array}$ \\
\hline Moderate (2) & Only two criteria are performed correctly. \\
\hline Less (1) & Only one criterion was performed correctly. \\
\hline Score & The final attifude makes the movement \\
\hline Good (3) & $\begin{array}{l}\text { 1) Dribble in a direction that is not controlled by the opponent. } \\
\text { 2) Help a friend to master the attack area. } \\
\text { 3) Running with the ball. }\end{array}$ \\
\hline Moderate (2) & Only two criteria are performed correctly. \\
\hline Less (1) & Only one criterion was performed correctly. \\
\hline \multicolumn{2}{|l|}{ Coordination } \\
\hline Score & The initial attitude of doing the movement \\
\hline Good (3) & $\begin{array}{l}\text { 1) Start with a standing posture. } \\
\text { 2) The gaze is always looking at the ball. } \\
\text { 3) The body is to the side of the ball. }\end{array}$ \\
\hline Moderate (2) & Only two criteria are performed correctly. \\
\hline Less (1) & Only one criterion was performed correctly. \\
\hline Score & The attitude of carrying out the movement \\
\hline Good (3) & $\begin{array}{l}\text { 1) Knees slightly bent. } \\
\text { 2) Push the ball forward using your inner, outer and instep. } \\
\text { 3) The feet that do not push the ball ensure that they are opened and balanced. }\end{array}$ \\
\hline Moderate (2) & Only two criteria are performed correctly. \\
\hline Less (1) & Only one criterion was performed correctly. \\
\hline Score & The final attitude makes the movement \\
\hline Good (3) & $\begin{array}{l}\text { 1) Stop the ball with your foot on top of the ball. } \\
\text { 2) Ensure that your body weight is on the unused leg. } \\
\text { 3) Look straight ahead. }\end{array}$ \\
\hline Moderate (2) & Only two criteria are performed correctly. \\
\hline Less (1) & Only one criterion was performed correctly. \\
\hline \multicolumn{2}{|l|}{ Ball Feeling } \\
\hline Score & The initial attitude of doing the movement \\
\hline Good (3) & $\begin{array}{l}\text { 1) The ball is at rest. } \\
\text { 2) The gaze is always looking at the ball. } \\
\text { 3) Put the bottom of the foot / sole / sole of the shoe onto the ball. }\end{array}$ \\
\hline Moderate (2) & Only two criteria are performed correctly. \\
\hline Less (1) & Only one criterion was performed correctly. \\
\hline Score & The attitude of carrying out the movement \\
\hline Good (3) & $\begin{array}{l}\text { 1) The position of the feet is on the side of the ball. } \\
\text { 2) Passing the first touch cone when receiving the ball must go to the next } \\
\text { target } \\
\text { 3) Move the ball in a direction that is not controlled by the opponent. }\end{array}$ \\
\hline Moderate (2) & Only two criteria are performed correctly. \\
\hline Less (1) & Only one criterion was performed correctly. \\
\hline Score & The final attifude makes the movement \\
\hline Good (3) & $\begin{array}{l}\text { 1) The ball will always move from one place to another. } \\
\text { 2) Get the ball. } \\
\text { 3) Help a friend to master the attack area }\end{array}$ \\
\hline Moderate (2) & Only two criteria are performed correctly. \\
\hline Less $(1)$ & Only one criterion was performed correctly. \\
\hline
\end{tabular}

The following is the processing of scores

Student acquisition score: SP

Skill scores obtained by students: SP/9 X 100

$$
\text { Value }=\frac{\text { Total score gains }}{\underset{\times}{\text { total maximum score }}}
$$

\section{Discussion}

Some things that can be recommended from the results of this study are:

1.For research subjects, students must be able to know things related to the basic skills, strategies, and formations presented by the coach, so that mistakes do not occur again in soccer dribbling.

2.For schools, giving awards and appreciation is very necessary if you get good results in each competition because it is to motivate elementary school students to increase their achievements both academically and non-academically.

\section{CONCLUSIONS}

This research can be concluded that the form of errors in the dribbling skills of class III and IV extracurricular football at Al-Fath BSD Elementary School, South Tangerang City is $18 \%$ first touch, $45 \%$ coordination, and $15 \%$ ball feeling, this can be seen in table 1 about the results of the assessment of the basic skill level of the game of football. According to (Draganidis et al., 2013; Hoare, 1994; Weigelt et al., 2000) in addition to playing soccer, students and teachers/coaches must know the level of performance recovery after practicing soccer, to return the muscles that have contracted to normal. According to (Smyth \& Anderson, 2001) time spent playing soccer is not a pure measure of the ability or effort of a child with good soccer skills who may often play soccer, but so are children who are highly motivated and like to play.

With this kind of research, the authors hope that it can be developed further and search for new problems and the next best results. Hopefully, the 
results of this study can become a reference for other writers and researchers.

\section{REFERENCES}

Afonshin, V., Drandrov, G., Burtsev, V., \& Polevchikov, M. (2020). Teaching football-players the techniques of dribbling and stroke using digital technologies in terms of interactive training complex. BIO Web of Conferences, 26, 00044. https://doi.org/10.1051/bioconf/ 20202600044

Anggraeni, D. ., \& Saryono. (2013). Metodelogi Penelitian Kualitatif dan Kuantitatif Dalam Bidang Kesehatan. Nuha Medika.

Ariningsih, N., Sumarwati, S., \& Saddhono, K. (2012). Analisis Kesalahan Berbahasa Indonesia Dalam Karangan Eksposisi Siswa Sekolah Menengah Atas. Jurnal Penelitian Bahasa, Sastra Indonesia, Dan Pengajarannya, 1(1), 130-141.

Asbari Masduki, Priyono Budi Santoso,

A. P. (2019). PENGARUH KEPEMIMPINAN

DAN BUDAYA ORGANISASI TERHADAP PERILAKU KERJA INOVATIF PADA INDRUSTRI 4.0. Jurnal Ilmiah Manajemen Universitas Putera Batam, 8(1), 7-15.

Danurwindo, Ganesha, P., Barry, S., \& Prahara, J. L. (2017). Kurikulum Pembinaan Sepakbola Indonesia PSSI. 5.

Draganidis, D., Chatzinikolaou, A., Jamurtas, A. Z., Carlos Barbero, J., Tsoukas, D., Theodorou, A. S., Margonis, K., Michailidis, Y., Avloniti, A., Theodorou, A., Kambas, A., \& Fatouros, I. (2013). The time-frame of acute resistance exercise effects on football skill performance: The impact of exercise intensity. Journal of Sports Sciences, 31(7), 714-722. https://doi.org/10.1080/0264041 4.2012.746725

Evan, B., Zask, A., Barnett, L., \& Dietrich, U. C. (2002). Fundamental movement skills How do primary school children perform? The "move it groove it" program in rural Australia. Journal of Science and Medicine in Sport, 5(3), 244-252. https://doi.org/10.1016/S14402440(02)80010-X

Giordano, L., Federici, A., Valentini, M., \& D'elia, F. (2019). Dribbling in football: Confronting learning theories. Journal of Human Sport and Exercise, 14(Proc2), S228$\mathrm{S} 232$.

https://doi.org/10.14198/jhse.20 19.14.Proc2.10

Hidayat, A. (2017). Peningkatan Aktivitas Gerak Lokomotor, Non Lokomotor dan Manipulatif Menggunakan Model Permainan Pada Siswa Sekolah Dasar. Jurnal Pendidikan Jasmani Dan Olahraga, 2(2), 21-29.

Hoare, D. (1994). Subtypes of developmental coordination disorder. Adapted Physical Activity Quarterly, 11(2), 158169.

https://doi.org/10.1123/apaq.11. 2.158

Hopper, Crhistopher A.; Davis, M. S. (1988). Coaching Soccer Effectively. The American Coaching Effectiveness Program. Level 1 Soccer Book. In Coaching Soccer Effectively. The American Coaching Effectiveness Program. Level 1 
Soccer Book. Human Kinetics Books.

Jayusman, I., \& Shavab, O. A. K. (2020). Aktivitas Belajar Mahasiswa Dengan Menggunakan Media Pembelajaran Learning Management System (Lms) Berbasis Edmodo Dalam Pembelajaran Sejarah. Jurnal Artefak, $\quad 7(1), \quad 13$. https://doi.org/10.25157/ja.v7i1. 3180

Putra, E. A. (2015). Anak Berkesulitan Belajar di Sekolah Dasar SeKelurahan Kalumbuk Padang. Jurnal Ilmiah Pendidikan Khusus, 1(3), 71-76. http://103.216.87.80/index.php/j upekhu/article/viewFile/6065/47 07

Sidabutar, R. (2020). Survey Kualitas Pembelajaran di Masa Study From Home. 02(01), 24-29.

Smyth, M. M., \& Anderson, H. I. (2001). Football participation in the primary school playground: The role of coordination impairments. British Journal of Developmental Psychology, 19(3), 369-379. https://doi.org/10.1348/0261510 01166155

Suherman, A. (2018). Kurikulum Pembelajaran Penjas (M. N. Alif (ed.); Kesatu).

Suherman, \& Sari, R. E. (2019). Perancangan Aplikasi Pembuatan Formasi Sepak Bola Interaktif Dengan Macromedia Flash. Journal of Maritime and Education, $\quad$ l(1), 1. http://ejournal.poltekamimedan.ac.id/

Sultoni, Imam Gunawan, F. D. P. (2018). Perbedaan Motivasi Belajar Mahasiswa Antara Sebelum Dan Sesudah
MENGIKUTI PELATIHAN MOTIVASIONAL. Jurnal Kajian Teori Dan Praktik Kependidikan, $3, \quad 1$. http://journal2.um.ac.id/index.ph $\mathrm{p} / \mathrm{jktpk}$

Taufik, $\quad$ M. S. (2019). MENINGKATKAN TEKNIK DASAR DRIBBLING SEPAKBOLA MELALUI MODIFIKASI PERMAINAN. Pendidikan Jasmani Kesehatan Dan Rekreasi, 8, 26-36.

Taufiqurriza, H. (2012). Tingkat Keterampilan Dasar Permainan Sepak Bola Pada Siswa Sekolah Dasar. Active - Journal of Physical Education, Sport, Health and Recreation, 1(1), 13.

https://doi.org/10.15294/active.v $1 \mathrm{i} 1.266$

Valentini, M., Riccardi, F., Raiola, G., \& Federici, A. (2018). Educational research: Motor area and relational area during children's personality development. Journal of Physical Education and Sport, 18(5), 2157-2174. https://doi.org/10.7752/jpes.201 8.55327

Viggita, D., \& Arikunto, S. (2020). Hubungan Antara Minat Belajar Dengan Prestasi Belajar Pada Siswa Kelas X Sma Negeri 1 Kutasari Di Purbalingga. Doctoral Dissertation, Universitas Ahmad Dahlan, 1-7.

Weigelt, C., Williams, A. M., Wingrove, T., \& Scott, M. A. (2000). Transfer and motor skill learning in association football. Ergonomics, 43(10), 16981707.

https://doi.org/10.1080/0014013 00750004104 